ELORE (ISSN 1456-3010), vol. 18 - 1/2011.

Julkaisija: Suomen Kansantietouden Tutkijain Seura ry.

[http://www.elore.fi/arkisto/1_11/ajank_piela.pdf]

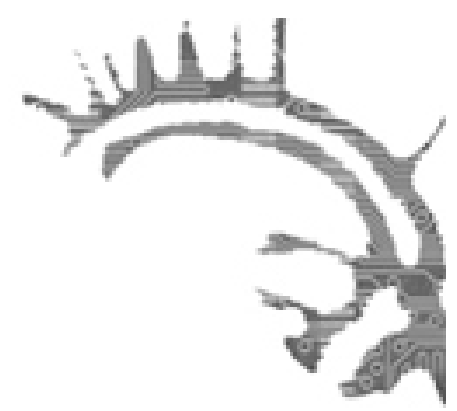

\title{
Ajankohtaista
}

\section{KANSA SAIRASTAA, PARANTAA JA KERTOO}

\section{$\underline{\text { Ulla Piela }}$}

Lectio praecursoria Itä-Suomen yliopistossa 27.11.2010

Suomen kielessä ja suomalaisissa tutkimuksissa termeillä kansanparannus, kansanlääkintä ja etnomedisiina tarkoitetaan kansanomaisia käsityksiä terveydestä ja sairaudesta. Kyse on hoitomuodoista, jotka jäävät edelleen Suomen yliopistoissa lääketieteellisen opetuksen ja tutkimuksen sekä yhteiskunnan virallisen terveydenhuollon ulkopuolelle. Jaottelu kansanlääkintään ja lääketieteeseen on kuitenkin teoreettinen, sillä käytännössä ne ovat aina olleet useiden sairauksien diagnosoinnissa ja hoidossa toisistaan riippuvaisia. Termi kansanomainen tarkoittaa parantamisen kontekstissa kansan keskuudesta ja tarpeista lähtöisin olevia tulkintoja terveydestä, sairaudesta ja niiden hoitamisesta. Kysymys on siis maallikoiden lääkinnällisestä tiedosta, joka rakentuu pääasiallisesti suullisen perinteen ja käytännössä opittujen taitojen avulla kotipiirissä. (NaakkaKorhonen 1997, 47-49.)

Kansanomaisista terveys- ja sairauskäsityksistä puhuttaessa on olennaista ymmärtää, että niihin vaikuttavat samat maailmankuvalliset ainekset, jotka määrittelevät muutenkin ihmisten tapaa hahmottaa todellisuutta (Knuuttila 2008, 54-65). Tällaisia maailmankuvallisia aineksia ovat muun muassa kulttuurisesti määrittyvät myyttiset mielikuvat, maaginen sanakäsitys ja maagiset uskomukset asioiden välisistä suhteista, usko tuonpuoleiseen, uskonto sekä luottamus perinteeseen, kokemukseen, tieteeseen ja auktoriteetteihin. Nämä käsitykset, mukaan lukien käsitykset sanasta tekona (Pihlström 2009,13-24) ja todellisuutta muuttavana voimana, eivät ole muokanneet vain menneisyyden ihmisen ajattelua, vaan niiden avulla me tulkitsemme ja määrittelemme edelleenkin terveyttä ja sairautta. Käsitysten keskinäinen painotus vaihtelee kuitenkin sen mukaan, minkälaiset terveys- ja sairauskäsitykset kyseisessä kulttuurissa 
Ulla Piela: Kansa sairastaa, parantaa ja kertoo

ovat hyväksyttyjä, minkälainen on terveydenhuoltojärjestelmä ja minkälaisesta parannustapahtumasta on kysymys.

Kansanparannuksen kontekstissa ihmisen keho, ruumis, on avoin, vaikutuksille altis, aukkoinen ja väylämäinen tila, jota muu todellisuus jatkuvasti merkityksellistää. Ruumiilliset kokemukset terveydestä ja sairaudesta saavat kulttuurisen merkityksensä aina siis suhteessa johonkin toiseen, ihmiseen tai ympäristöön. Suullisen perinteentutkimuksen näkökulmasta kansanlääkinnässä on siis kyse sosiaalisessa vuorovaikutuksessa muodostuvasta kulttuurisesta tiedosta, joka koskee ruumiin ja sen ulkopuolelle hahmottuvan todellisuuden välistä suhdetta. Käsitykset terveydestä ja sairaudesta muodostuvat juuri tämän suhteen tulkinnoissa. On kuitenkin niin, että tulkinnat tästä suhteesta muuttuvat sitä mukaa kuin parantamisen tavat ja kansanlääkinnällinen tieto muuttuvat.

\section{PitKäKestoiset ajat'Telumallit terveys- Ja SAIRAUSKÄSITYSTEN TAUSTALLA}

Kuinka tulkinnat terveydestä ja sairaudesta ovat sitten muuttuneet agraarisen Suomen modernisoituessa? Miten parantamiseen liittyvät erilaiset perinnetekstit ilmentävät niissä tapahtuneita muutoksia? Mistä näihin kysymyksiin voi etsiä vastauksia ja millaisin menetelmin?

Kysymysten kannalta Pohjois-Karjala on osoittautunut otolliseksi kohteeksi, sillä alueelta on tallennettu huomattavat määrät kansanlääkintäaineistoja parinsadan vuoden ajalta. Tutkimuksessani aineistona on Pohjois-Karjalasta 1800- ja 1900-luvuilla sekä 2000-luvun alussa tallennettu kansanparannuksesta kertova suullinen perinne. Valtaosa aineistosta on myyttisiä mielikuvia ja maagisia uskomuksia ilmentäviä parannusloitsuja. Muut tekstit ovat etnografisia kuvauksia parannustapahtumista ja kansanlääkintään liittyvää muistitietoa.

Moniaineistoisuus eli eri aikakausina tallennettujen ja useita perinnelajeja edustavien tekstien tarkasteleminen on tarpeen silloin, kun halutaan saada yleiskuva tietyn alueen ihmisten terveyttä ja sairautta koskevasta kulttuurisesta ajattelusta sekä selvittää ilmiöitä, jotka liittyvät ja vaikuttavat laaja-alaisina ihmisten ja yhteisöjen toimintoihin. Kansanomaiset käsitykset terveydestä ja sairaudesta ovat juuri tällaisia varsin kattavasti ihmisten toimintaan vaikuttavia käsityksiä, joiden tutkimisessa erityyppiset ja -aikaiset aineistot täydentävät toisiaan. Käyttämiäni aineistoja on kolme. Riittiparantamiseen liittyvä kalevalamittainen loitsuaineisto on vanhinta ja määrällisesti laajinta. Toinen aineisto käsittää Sanomalebti Karjalaisen ja Karjalan tutkimuslaitoksen vuonna 1974 järjestämän lukijakilpailun vastaukset. Kolmas aineisto on Sanomalehti Karjalaisen ja Kansanrunousarkiston järjestämän lukijakilpailun satoa vuodelta 2002. Kaikkiaan aineisto eri perinnelajeineen muodostaa kiinnostavan läpileikkauksen kansanomaisen parantamisen historiasta, sen kulttuurisista merkityksistä sekä terveys- ja sairauskäsitysten muuttumisesta Pohjois-Karjalassa kahden sadan vuoden ajalta.

On selvää, että kerronnan konteksti vaikuttaa käsitysten muodostumiseen ja samalla niiden merkityksiin. Jotta saataisiin selville, kuinka tulkinnat terveydestä ja 
sairaudesta konstruoidaan ja merkityksellistetään muun kuin parannustapahtuman yhteydessä ja muissa perinteenlajeissa kuin parannusloitsuissa ja kansanlääkinnällisissä etnografisissa kuvauksissa, on tarkastelua syytä laajentaa myös muihin esityskonteksteihin ja teksteihin. Mahdollisuuksia on monia. Tutkimuksessani olen päätynyt tarkastelemaan Mekrijärvellä eläneen kalevalamittaisen runokulttuurin ilmaisukeinot laajasti hallitsevan laulaja-tietäjä Simana Sissosen (1786-1848) eeppisiä runoja sekä Polvijärvellä eläneiden Lyyli Homeen (1901-1982) ja Aarne Karttusen (1914-2006) omaelämäkerrallisia tekstejä.

Kehyksen näille keskenään varsin erilaisten tekstien tulkinnoille muodostavat tutkimuksessani toisiinsa liittyvät tieteenfilosofiset suuntaukset hermeneutiikka ja konstruktionismi sekä niihin tukeutuva ranskalaisen filosofin Paul Ricoeurin teoria mimesiksestä kulttuurisen kompetenssin narratiivisena prosessoitumisena. ${ }^{1}$ Tästä näkökulmasta tarkastelen kansanparannusta kulttuurisen ruumiin ja todellisuuden välisenä suhteena, jonka kerronnallisin keinoin esitetyissä tulkinnoissa käsitykset terveydestä ja sairaudesta konstruoituvat ja merkityksellistyvät aina uudestaan. Parantamiseen liittyvät perinnelajit voidaan näin nähdä kansanlääkinnällisen tiedon uudelleentulkintoina ja koetinkivinä, joiden avulla määritellään aina uudestaan yhteisössä vallitsevat käsitykset terveydestä ja sairaudesta.

Tarkastellessani kerronnan avulla tapahtuvia terveyden ja sairauden tulkintoja on keskeiseksi käsitteeksi muodostunut narratiivi. Käsite juontuu narratiivisesta psykologiasta sekä narratiivisuuteen eli kerronnallisuuteen liittyvästä tutkimusperinteestä. Oma määrittelyni siitä nojaa amerikkalaisen kognitiivisen psykologin Jerome Brunerin näkemyksiin. Hänen mukaansa narratiivi on sekä kulttuurisesti muotoutuva kognitiivinen väline, jonka avulla todellisuutta hahmotetaan kerronnallisesti, että tämän prosessin representaatio, esimerkiksi parannustapahtumassa kuullun loitsun uudelleen tulkinta. (Bruner 1985; 1987.) Tutkimuksessani narratiivi on siis hermeneuttisesti muodostuva konstruktio. Se on kerronnan avulla luotua merkityssisältöä, joka viittaa kerrontaan prosessina ja merkitykseen sen lopputuloksena. Narratiivi on siis kertomalla tuotettu merkitys koetusta todellisuudesta. (Bruner 1987, 15; Riessman 1993, 4, 70.)

Kognitiivisen psykologian mukaan ihminen jäsentää havaitsemastaan todellisuudesta saatua informaatiota kategorioiden avulla ja toimii niiden perusteella (Anttonen 1996, 25-27; Saariluoma 2001, 30, 39, 42, 44). Ne viittaavat ihmisen kykyyn havainnoida, jäsentää ja järjestää mielessään ja kerronnassaan maailmasta tulvivaa tietoa. Tutkimusaineistoni lähiluku paljasti, että kaikissa kerrontakonteksteissa todellisuus jäsentyy kognitiivisten kategorioiden avulla kahdeksi kulttuurisen tietoisuuden alueeksi. Olen nimennyt nämä kulttuurisen tietoisuuden alueet käsitteillä tämä maailma ja vastamaailma. A. J. Greimasin (1980) ajattelua mukaillen ne ovat kontraarisessa vastavuorosuhteessa: ne ovat olemassa samanaikaisesti, ne edellyttävät toisiaan ja vaikuttavat toisiinsa. Tämä maailma ja vastamaailma ovat olennainen osa narratiivia, tekstin merkityssisältöä. Tämä maailma tarkoittaa reaalimaailmaa, sitä elämänpiiriä, missä kertoja elää, toimii,

1 Hermeneutiikasta Gadamer 2004; konstruktionismista Berger \& Luckmann 2003; Gergen 2001; Hacking 2009; mimesiksestä Ricoeur 1984, 52-76; Kaunismaa \& Laitinen 1998, 179-186; Aarnipuu 2008, 35-38. 
Ulla Piela: Kansa sairastaa, parantaa ja kertoo

merkityksellistää ja konstruoi narratiivisesti kokemaansa todellisuutta. Vastamaailma on muualla kuin täällä. Se on paikallisuus, jossa vaikuttavat yliluonnolliset olennot, jumaluudet, vainajat, haltijat sekä pahantahtoiset ihmiset.

Terveyttä ja sairautta määriteltäessä todellisuuden kategoriointi kahdeksi kulttuuriseksi alueeksi on säilynyt läpi vuosisatojen siitä huolimatta, että ihmisten terveystieto ja terveydenhoitotavat ovat täydellisesti muuttuneet. Kyse on siis pitkäkestoisesta ajattelumallista, joka vaikuttaa edelleenkin terveys- ja sairauskäsitystemme narratiiviseen prosessoitumiseen.

\section{MuUtTUVAT MAaIlMat Ja KaNSANPARANNUS}

Kalevalamittaisten parannusloitsujen, riittien ja maagisten menettelyiden tuntemus oli Pohjois-Karjalassa varsin yleistä koko 1800-luvun ja vielä 1900-luvun alussakin. Riittiparantamisen kontekstissa käsitykset terveydestä, sairaudesta ja parantamisesta pohjautuivat myyttisiin mielikuviin, maagiseen sanakäsitykseen, uskoon tuonpuoleisesta ja yliluonnollisesta sekä kokemusperäisessä perheparannuksessa karttuneisiin tietoihin. Sekä sairauden että terveyden ajateltiin tulleen ihmisen hallitseman kotipiirin ulkopuolelta, vastamaailmasta. Sairaus paikantuu parannusriiteissä vastamaailmaan sijoittuvaan anomaliseen luontoon, tuonpuoleiseen, pahantahtoisiin ihmisiin ja muihin taudinaiheuttajiin. Terveyskin on mahdollista saada luonnosta, mutta myös vastamaailmaan sijoittuvasta taivaasta sekä hyväntahtoisilta yliluonnollisilta olennoilta. Parannusriittien kulttuurinen tieto terveydestä ja sairaudesta kiteytyy käsityksessä "siitä parannus, mistä tauti".

Modernisaation myötä maaginen sanakäsitys ja maagiset uskomukset asioiden välisistä suhteista vähitellen väistyivät 1800- ja 1900-luvun vaihteessa, mutta riiteissä käytetyt parantaviksi ymmärretyt tavat säilyivät. Vielä vuosisadan puolivälissäkin pohjoiskarjalaisten kotona suoritettu perheparannus perustui ilman riittejä suoritettuun kokemusperäiseen kansanlääkintään, jota täydennettiin sekä ammattiparantajien että lääkäreiden tiedoilla ja tehostettiin tarvittaessa maagisilla menetelmillä. Suhde luontoon oli pragmaattinen. Se koettiin osaksi ihmisen itsensä hallitsemaa tätä maailmaa, ihmisen hyvinvointia ja terveyttä tukevaa kotipiiriä. Sairauksia aiheuttavaksi vastamaailmaksi paikantui kansakunnan ja hyvinvointivaltion rakennusprojektissa kodin ulkopuolinen yhteiskunta velvollisuuksineen ja vaatimuksineen. Kun vastamaailma sekularisoitui tarkoittamaan yhteiskuntaa ja velvollisuuksia, sellaista riittiä, jossa yliluonnollisella ja uskonnolla on tärkeä osa, ei enää tarvittu. Käsitys "siitä parannus, mistä tauti" ei enää pätenyt.

2000-luvun alussa pohjoiskarjalaisten terveys- ja sairauskäsityksissä ja perheparannuksessa näkyy selvimmin lääketieteen vaikutus, jota täydennetään sen ulkopuolelle jäävillä niin sanotuilla vaihtoehtoisilla hoitomuodoilla. Näitä ovat muun muassa luonnonlääkkeillä hoitaminen, kiropraktiikka, naprapatia, kuppaus, hieronta, akupunktuuri, rentoutushoito ja homeopatia. Modernin perheparantamisen ja itsehoidon kontekstissa kodin ulkopuolinen maailma prosessoituu työn ja velvollisuuksien yhteiskuntana vastamaailmaksi, jonne myös ruumiillisten ja henkisten vaivojen alkuperä useimmiten projisoidaan. 
Ulla Piela: Kansa sairastaa, parantaa ja kertoo

\section{RASVAKESKUSTELUN KULTTUURISET AJATTELUMALLIT}

Vaikka suomalaisten terveys väestötasolla kaiken aikaa paranee ja elinikä pitenee, uudet terveysuhat nousevat aika ajoin kiivaankin keskustelun aiheeksi. Viime aikoina on kiistelty siitä, ovatko niin sanotut kovat rasvat eli tyydyttyneet eläinrasvat sittenkään niin haitallisia kuin meidät on aiemmin opetettu uskomaan. Kovilla rasvoilla ei ehkä olekaan niin haitallista vaikutusta sydämen terveyteen kuin on luultu, vaan niitäkin pahemman riskin muodostavat nopeat hiilihydraatit, sokeri ja valkoinen vilja. Suuri yleisö on hämmentynyt: kehen voi luottaa, uskoako virallisia terveysauktoriteetteja vai ei? (Helsingin Sanomat, 2010).

Rasvakeskustelu on loistava esimerkki siitä, että yksimielisyyttä terveys- ja sairauskäsityksistä ei ole olemassa. Keskustelu on lainehtinut laidasta laitaan niin kodeissa, työpaikoilla, mediassa kuin nettisivustojen palstoilla. Kovien rasvojen puolestapuhujat eivät kaihda voita ja kermaa. He muistelevat lapsuutensa ruokapöytiä, joissa kermaa, kananmunia, rasvaisia juustoja ja lihaa ei säästelty ja kertovat, että suvussa on paljon pitkäikäisiä ihmisiä, jotka tällä ruokavaliolla ovat eläneet terveinä loppusuoralle saakka. Kovien rasvojen puolestapuhujat vetoavat kertomuksissaan siis menneisyyteen: siihen maailmaan, jonne terveys onkin kansanomaisissa käsityksissä usein projisoitu. Tämän ajatuskulun mukaan syömällä samalla tavalla kuin aiemmat sukupolvet on siis mahdollista saada menneisyys takaisin tänne, tähän nykymaailmaan. Menneisyys näyttäytyy näin terveyttä nykyisyyteen tuottavana vastamaailmana ja nykyisyys vääränlaisine ruokapuheineen sairautta aiheuttavana reaalitodellisuutena, maailmana tässä ja nyt.

Kiinnostavan lisän tähän keskusteluun tuo se, että kovien rasvojen puolustajat ovat hyökänneet myös Pohjois-Karjalassa 1970-luvulla aloitetun terveydenedistämisprojektin kimppuun. Projektin tarkoituksena oli vähentää eläinrasvojen käyttöä ja alentaa näin kohonnutta verenpainetta. Rasvojen puolustajat näkevät nyt projektin syyllistyneen värärälaisen terveysvalistuksen levittämiseen, vieneen heiltä väärin perustein mahdollisuuden hyvän menneisyyden kokemiseen.

Kovien rasvojen vastustajat kertovat puolestaan korkeasta kolestrolista, verenpaineesta, liikakiloista, diabeteksesta ja monista muista vaivoista ja sairauksista. Heidän käsityksensä terveydestä perustuvat siihen viralliseen terveysvalistukseen, jota jaettiin vuosikymmenet ennen rasvakeskustelun alkua sekä niihin uusmoderneihin kansanomaisiin terveydenhoitotapoihin, joihin kuuluvat muun muassa paastoaminen, kasvisruoka, luonnonlääkkeet, akupunktuuri ja rentoutushoidot. Kyse on hoidoista, joilla haetaan tasapainoa oman ruumiin ja elämismaailman sekä niiden ulkopuolelle hahmottuvan todellisuuden, erityisesti niin sanotun virallisen yhteiskunnan välille. Kovien rasvojen vastustajille terveys on henkilökohtainen projekti, jota ei tuoteta menneisyyttä nostalgisoimalla, vaan nykyisyyden, tämän maailman, mahdollisuuksia hyödyntämällä.

Ravintoaineisiin liittyvän tutkimustiedon lisääntyessä on opittu ymmärtämään, ettei kaikille sopivaa ravintosuositusta voi olla olemassa. Myöskään terveydestä ja sairaudesta ei päästä yksimielisyyteen, sillä vaikka terveydentilalla onkin fysiologiset syynsä ja seurauksensa, se on aina myös subjektiivinen ja kokemuksellinen tila, jonka henkilökohtaiseen tulkintaan ja merkityksenantoon vaikuttavat kulttuurin ja yhteisön 
Ulla Piela: Kansa sairastaa, parantaa ja kertoo

erityispiirteet. Käsityksemme terveydestä ja sairaudesta eivät rakennu siis mitatulle faktalle, vaan ruumiillisten kokemusten herättämille ajatuksille, muistoille ja mielikuville, jotka saavat erilaisia ilmauksia suullisessa perinteessä: parannusloitsuissa, sananparsissa, saduissa, kaskuissa ja vitseissä, etnografisissa kuvauksissa, elämäkerroissa sekä päivittäisessä puheen virrassa.

\section{KOHTI TERVEYS- JA SAIRAUSKÄSITYSTEN MONIAINEISTOISTA TUTKIMUSTA}

Terveyden ja sairauden tulkinnat eivät luonnollisestikaan kuulu vain suulliseen perinteeseen. Kipuun, sairauteen ja terveyteen liittyvien kokemusten ja tuntemusten tulkintaan pääsee osalliseksi miltei tahansa niin korkean kuin matalan kulttuurin parissa: elokuvissa, sarjakuvissa, teatterissa, kirjallisuudessa ja kuvataiteessa. Keravan taidemuseossa oli kesällä 2010 näyttely, jonka nimi oli Kipu - näkökulmia kivun anatomiaan. Näyttelyssä 16 taiteilijaa purki maalauksissaan, veistoksissaan ja installaatioissaan kivun käsitettä ja sen ilmenemismuotoja. Kipua ja kärsimystä ei käsitelty niissä ihmistä ylevöittävinä ja jalostavina tuntemuksina, vaan omien fyysisten ja psyykkisten kokemusten arkisina havainnointeina, jotka osoittivat terveyden ja sairauden välisen rajan veteen piirretyksi viivaksi. Näyttelyluettelossa muistutettiin myös, että kivun ja kärsimyksen kuvaaminen kulkee taiteen historiassa suurena linjana samaan tapaan kuin kauneus, sankaruus ja jumaluus (Heinänen 2010). Tulkinnat terveydestä ja sairaudesta läpäisevät siis kaikki kulttuuriset ilmaisumuodot laidasta laitaan. Kysymys on ihmisten maailmankuvaa ylläpitävistä, luovista ja muuttavista käsityksistä, joiden moniaineistoinen tutkimus on Suomessa vasta alussa.

Piela, Ulla 2010: Kansanparannuksen kerrotut merkitykset Pobjois-Karjalassa 1800- ja 1900-luvuilla. Joensuu: Publications of the University of Eastern Finland. Dissertations in Education, Humanities, and Theology No 8. University of Eastern Finland.

[onlinęe] <http://urn.fi/URN:ISBN:978-952-61-0208-5>

\section{KirjallisuUs}

AARNIPUU, PETJA 2008: Turun linna kerrottuna ja kertovana tilana. Helsinki: SKS.

ANTTONEN, VEIKKO 1996: I hmisen ja maan rajat. 'Pyhä' kulttuurisena kategoriana. Helsinki: SKS.

BERGER, PETER L. \& LUCKMANN, THOMAS 2003 (4. painos): Todellisunden sosiaalinen rakentuminen. Helsinki: Gaudeamus.

BRUNER, JEROME 1985: Narrative and Paradigmatic Modes of Though. - Eisner, Elliot (toim.), Learning and Teaching the Ways of Knowing. Chicago: The University of Chicago Press.

BRUNER, JEROME 1987: Life as Narrative. - Social Research 54 (1).

GADAMER, HANS-GEORG 2004: Hermeneutiikkea. Ymmärtäminen tieteessä ja filosofiassa. 
Ulla Piela: Kansa sairastaa, parantaa ja kertoo

Tampere: Vastapaino.

GERGEN, KENNETH J. 2001: Social Construction in Context. London and Thousand Oaks, New Delhi: Sage.

GREIMAS, A.K. 1980 (1960): Strukturaalista semantiikkaa. Helsinki: Gaudeamus.

HACKING, IAN 2009: Mitä sosiaalinen konstruktionismi on? Tampere: Vastapaino.

HEINÄNEN, KAISA 2000: Kipu kahliutuu kuviin. - Helsingin Sanomat 5.6.2010.

HELSINGIN SANOMAT 20.9.2010 - Rasvakeskustelusta turhaa huolta.

KAUNISMAA, PEKKA \& LAITINEN, ARTO 1998: Paul Ricoeur ja narratiivinen identiteetti. - Kuhmonen, Petri \& Sillman, Seppo (toim.), Jaettu jana, ääretön raja. Jyväskylä: Jyväskylän yliopisto, Filosofian julkaisuja 65 .

KNUUTTILA, SEPPO 2008: Mentaliteetti, mieli ja merkitys. - Piela, Ulla \& Vakimo, Sinikka (toim.), Entinen aika, nykeyinen mieli. Helsinki: SKS.

NAAKKA-KORHONEN, MERVI 1997: Vaivasta taudiksi. Lapamatoon liittyvä kansanparannus erityisesti pobjoiskarjalaisen aineiston valossa. Helsinki: SKS.

PIHLSTRÖM, SAMI 2009: Sanoilla tekeminen - filosofinen näkökulma. - Knuuttila, Seppo \& Piela, Ulla (toim.), Korkeempi kaiku. Sanan magiaa ja puheen poetiikekaa. Kalevalaseuran vuosikirja 88. Helsinki: SKS.

RICOEUR, PAUL 1984: Time and Narrrative I. Chicago: The University of Chicago Press.

RIESSMAN, CATHRINE KOHLER 1993: Narrative Analysis. Qualitative Reseach Methods 30. Newbury Park: Sage.

SAARILUOMA, PERTTTI 2001: Moderni kognitiotiede. - Saariluoma, Pertti, Kamppinen, Matti \& Hautamäki, Antti (toim.), Moderni kognitiotiede. Helsinki: Gaudeamus.

TARKKA, LOTTE 2005: Rajarahvaan laulu. Tutkimus Vuokkiniemen kalevalamittaisesta runokulttuurista 1821-1921. Helsinki: SKS.

\section{Filosofian tohtori Ulla Piela on Kalevalaseuran toiminnanjohtaja.}

